\title{
Age and origin of peridotitic diamonds from Venetia, Limpopo Belt, Kaapvaal-Zimbabwe Craton
}

\author{
S.H. Richardson ${ }^{1}$, P.F. Pöml ${ }^{2}$, S.B. Shirey ${ }^{3}$, and J.W. Harris ${ }^{4}$ \\ ${ }^{1}$ Dept. of Geological Sciences, University of Cape Town, Rondebosch 7701, South Africa \\ ${ }^{2}$ Institut für Mineralogie, Westfälische Wilhelms-Universität, 48149 Münster, Germany \\ ${ }^{3}$ Dept. of Terrestrial Magnetism, Carnegie Institution of Washington, 5241 Broad Branch Road NW, \\ Washington DC 20015, USA \\ ${ }^{4}$ Dept. of Geographical \& Earth Sciences, University of Glasgow, Glasgow G12 8QQ, UK
}

The age and origin of diamonds from the Venetia mine, Limpopo Belt, Kaapvaal-Zimbabwe Craton, have been investigated using the $\mathrm{Sm}-\mathrm{Nd}$ and $\mathrm{Rb}-\mathrm{Sr}$ isotope systems in peridotitic garnet inclusions and selected macrocrysts and the Re-Os system in sulfide inclusions. The $520 \mathrm{Ma}$ Venetia kimberlite cluster is located in the Central Zone of the Limpopo Belt (Phillips et al., 1999; Seggie et al., 1999) where Archean crust has experienced at least two major tectonothermal events at ca. 2.6 and 2.0 Ga (Eglington \& Armstrong, 2004; Boshoff et al., 2006). The first age may represent the time of amalgamation of the Kaapvaal and Zimbabwe cratonic nuclei by subduction-accretion processes some 2.7 - 2.5 Ga ago, while the second age overlaps the well-constrained 2.054 Ga emplacement age (Scoates \& Friedman, 2007) of the Bushveld Complex.

Peridotitic garnet inclusions in Venetia diamonds are harzburgitic to lherzolitic in composition with low $\mathrm{Ca}$ and high $\mathrm{Cr}$ contents spanning the entire G10 garnet field. Garnet macrocrysts generally have less extreme $\mathrm{Ca}$ and $\mathrm{Cr}$ contents and represent the disaggregated mantle host rocks of at least some of the diamonds. Using Ca content as a proxy for Sm/Nd ratio, some 140 inclusions were combined into four $\mathrm{Ca}-\mathrm{Cr}$ groups to obtain sufficient material for meaningful Sm-Nd and $\mathrm{Sr}$ isotope analysis. All the garnet inclusions and macrocrysts have negligible $\mathrm{Rb}$ contents. The garnets encapsulated in diamond have high $\mathrm{Sr}$ and $\mathrm{Nd}$ concentrations and low $\mathrm{Sm} / \mathrm{Nd}$ inversely correlated with $\mathrm{Ca}$. The garnet macrocrysts also show low but more scattered $\mathrm{Sm} / \mathrm{Nd}$ and much more radiogenic $\mathrm{Sr}$ (up to 0.720).This suggests diffusive exchange of the unencapsulated garnet macrocrysts with their high $\mathrm{Rb} / \mathrm{Sr}$ host rocks during storage in the mantle keel on a billion-year timescale.

Three out of the four inclusion groups give a nominal isochron age of $2.30 \pm 0.04 \mathrm{Ga}$ with an unradiogenic initial $\left(\varepsilon_{\mathrm{Nd}}=-8\right)$. However, initial ${ }^{87} \mathrm{Sr} /{ }^{86} \mathrm{Sr}$ is inversely correlated with reciprocal $\mathrm{Sr}$ and $\mathrm{Nd}$ concentration, indicating mixing between a low $\mathrm{Ca}$, low $\mathrm{Sm} / \mathrm{Nd}$, harzburgitic endmember with radiogenic $\mathrm{Sr}(\leq 0.707)$ and a higher $\mathrm{Ca}$, higher $\mathrm{Sm} / \mathrm{Nd}$, eclogitic endmember with less radiogenic $\mathrm{Sr}(<0.705)$, which slightly but significantly raised the initial $\mathrm{Nd}$ isotope ratios of the inclusion groups in proportion to the degree of mixing. Therefore, $2.3 \mathrm{Ga}$ is a maximum age for these diamonds. Even so, the initial Nd composition and the characteristics of the mixing array indicate a $>3 \mathrm{Ga}$ continental mantle harzburgite precursor to which an eclogitic component was added at ca. $2 \mathrm{Ga}$, as also suggested by the Re-Os isotope systematics of single sulfide inclusions in Venetia diamonds (Richardson \& Shirey, 2008).

One Venetia peridotitic sulfide inclusion has an unradiogenic Os isotope composition comparable to those of Venetia peridotite xenoliths with Archean Re depletion model ages (Carlson et al., 1999). Four Venetia eclogitic sulfide inclusions describe an approximately $2.05 \mathrm{Ga}$ Re-Os array with elevated initial ${ }^{187} \mathrm{Os} /{ }^{188} \mathrm{Os}$, supporting the presence of old eclogitic SCLM components equilibrated at Bushveld time. This initial ratio is even more radiogenic than those of Bushveld PGE sulfide ore minerals (Hart \& Kinloch, 1989; McCandless \& Ruiz, 1991) that have previously been attributed to continental crustal contamination (e.g. McCandless \& Ruiz, 1991; Schoenberg et al., 1999). The sulfide Re-Os data provide strong evidence that the main source of Bushveld PGE is the mantle rather than the crust (Richardson \& Shirey, 2008). Combined sulfide Re-Os and silicate $\mathrm{Sm}-\mathrm{Nd}$ and $\mathrm{Rb}-\mathrm{Sr}$ isotope compositions suggest variable incorporation of harzburgitic and eclogitic SCLM components during genesis of both the diamonds and the Bushveld Complex (Richardson \& Shirey, 2008).

In this scenario, the Venetia harzburgitic-to-lherzolitic diamonds crystallized (or recrystallized) at ca. $2 \mathrm{Ga}$, following emplacement of the Bushveld Complex. The Venetia garnet inclusions and macrocrysts show strong similarities to their harzburgitic-to-lherzolitic counterparts from the 1.2 Ga Premier kimberlite on the 
opposite side of the Bushveld Complex (Richardson et al., 1993), as well as the $370 \mathrm{Ma}$ Udachnaya kimberlite, Siberian Craton, where both Archean and Proterozoic generations of peridotitic diamonds have previously been identified (Richardson \& Harris, 1997; Pearson et al., 1999).

\section{References}

Boshoff, R., Van Reenen, D.D., Smit, C.A., Perchuk, L.L., Kramers, J.D., Armstrong, R., 2006. Geological history of the Central Zone of the Limpopo Complex: the West Alldays area. Journal of Geology 114, 699-761.

Carlson, R.W., Pearson, D.G., Boyd, F.R., Shirey, S.B., Irvine, G., 1999. Re-Os systematics of lithospheric peridotites: implications for lithosphere formation and preservation. In: The J.B. Dawson Volume (Eds. Gurney, J.J., Gurney, J.L., Pascoe, M.D., Richardson, S.H.) 99-108 (Red Roof Design, Cape Town).

Eglington, B.M., Armstrong, R.A., 2004. The Kaapvaal Craton and adjacent orogens, southern Africa: a geochronological database and overview of the geological development of the craton. South African Journal of Geology 107, 13-32.

Hart, S.R., Kinloch, E.D., 1989. Osmium isotope systematics in Witwatersrand and Bushveld ore deposits. Economic Geology 84, 1651-1655.

McCandless, T.E., Ruiz, J., 1991. Osmium isotopes and crustal sources for platinum-group mineralization in the Bushveld Complex, South Africa. Geology $19,1225-1228$.

Pearson, D.G., Shirey, S.B., Bulanova, G.P., Carlson, R.W., Milledge, H.J., 1999. Re-Os isotope measurements of single sulfide inclusions in a Siberian diamond and its nitrogen aggregation systematics.

Geochimica et Cosmochimica Acta 63, 703-711.

Phillips, D., Kiviets, G.B., Barton, E.S., Smith, C.B., Viljoen, K.S., Fourie, L.F. $1999 .{ }^{40} \mathrm{Ar} /{ }^{39} \mathrm{Ar}$ dating of kimberlites and related rocks; problems and solutions. In: The P.H. Nixon Volume (Eds. Gurney, J.J., Gurney, J.L., Pascoe, M.D., Richardson, S.H.) 677-688 (Red Roof Design, Cape Town).

Richardson, S.H., Harris, J.W., 1997. Antiquity of peridotitic diamonds from the Siberian craton. Earth and Planetary Science Letters 151, 271-277.

Richardson, S.H., Shirey, S.B., 2008. Continental mantle signature of Bushveld magmas and coeval diamonds. Nature 453, 910-913.

Richardson, S.H., Harris, J.W., Gurney, J.J., 1993. Three generations of diamonds from old continental mantle. Nature 366, 256-258.

Schoenberg, R., Kruger, F.J., Nägler, T.F., Meisel, T., Kramers, J.D., 1999. PGE enrichment in chromitite layers and the Merensky Reef of the western Bushveld Complex; a Re-Os and $\mathrm{Rb}-\mathrm{Sr}$ isotope study. Earth and Planetary Science Letters 172, 4964.

Scoates, J.S., Friedman, R.M. 2007. Determining the age and cooling history of the world's largest layered intrusion: $\mathrm{U}-\mathrm{Pb}$ zircon-rutile geochronology of the Merensky Reef, Bushveld Complex, South Africa. Eos Trans. AGU 88 (52), Fall Meeting Supplement, Abstract V43A-1102.

Seggie, A.G., Hannweg, G.W., Colgan, E.A., Smith, C.B. 1999. The geology and geochemistry of the Venetia kimberlite cluster, Northern Province, South Africa. In: The P.H. Nixon Volume (Eds. Gurney, J.J., Gurney, J.L., Pascoe, M.D., Richardson, S.H.) 750-756 (Red Roof Design, Cape Town). 
